\title{
Initial Stage of Development of Baikalskoe-1 Sanctuary Fortress Site
}

\author{
Artur V. Kharinskiy* \\ Irkutsk National Research Technical University \\ Irkutsk, Russian Federation
}

Received 10.10.2019, received in revised form 03.03.2020, accepted 30.04.2020

\begin{abstract}
Baikalskoe-1 sanctuary fortress site is located on the north-west coast of Lake Baikal. It occupies a cusp-like hill site on Cape Ludar, standing $80 \mathrm{~m}$ above the lake level. In the process of excavations, two culture-bearing strata were revealed in the territory of the site. The deeper stratum embraces the artefacts of the $2^{\text {nd }}-1^{\text {st }}$ millennia $\mathrm{BC}$, divided into two archaeological sites. The earlier is approximately dated with the early-mid $2^{\text {nd }}$ millennium BC. It is represented with the remains of clay Glazkov type pottery, quartzite and silicon items. Another archaeological site includes the artefacts datingback to the $6^{\text {th }} 1^{\text {st }}$ centuries BC. They include the fragments of Tyshkine (Senogda) type pottery, arrowheads, silicon scrapers and knives as well as the wastes of the production of such. The findings of Baikalskoe-1 prove that for four thousand years, the mount on the coast of Lake Baikal has been considered as a place where contact between the human world and deities was possible.
\end{abstract}

Keywords: Lake Baikal, Cape Ludar, sanctuary fortress site, culture-bearing stratum, Bronze Age, Glazkov pottery, quartzite items, Tyshkine (Senogda) pottery, arrowheads, scrapers, carbon dating.

Prepared under scientific project No. 15-31-01018 supported by Russian Humanitarian Science Foundation.

Research area: archeology.

Citation: Kharinskiy, A.V. (2020). Initial stage of development of Baikalskoe-1 sanctuary fortress site. J. Sib. Fed. Univ. Humanit. Soc. Sci., 14(1), 31-48. DOI: 10.17516/1997-1370-0569.

(C) Siberian Federal University. All rights reserved

* Corresponding author E-mail address: kharinsky@mail.ru, histor@istu.irk.ru ORCID: 0000-0002-4815-6069 


\section{Introduction}

Among various types of archaeological sites, fortress sites normally play one of the major roles. It is easy to explain, as this term usually refers to an reinforced settlement providing the researchers with various information on the life of an ancient fortress. But not all the sites traditionally referred to by the archaeologists as fortresses are reinforced. It can be illustrated by some materials found in the Cisbaikalia. Since the end of the $19^{\text {th }}$ century, the term fortress has referred to all the naturally reinforced sites (surrounded with rivers or ravines) and the sites protected with traditional dykes, earth mounds or walls. For the first time, the term was used in 1881 by N.N. Agapitov to refer to the archaeological findings he studied in $\mathrm{Ku}-$ dinskaya valley, formally reminding of the East European fortresses (Agapitov, 1881). The term got established and is often used for archaeological sites with no regard to their functional specificity. The mismatch of the term of a fortress as an reinforced settlement to the majority of the archaeological monuments of the Cisbaikalia surrounded by dykes and walls was ignored for a long time. It was caused, first of all, by the lack of proper studies. Only the archaeological research carried out in the late 1980s - early 1990-s around Lake Baikal provided new interpretation of such archaeological sites (Kharinskiy, 1994).

The Baikal fortresses were not reinforced settlements. Only four of them: Khargoi I, Shebete I, IV and Elantsino wall could be used as temporary shelters. The rest of the "fortresses" were, first of all, the cult centres. Obviously, they were used for praying to the presiding deities, and, later, to the spirits of the ancestors. The ceremonies were collective, attended by families or, maybe, even tribes. The participants of the services prayed to the members of their families or tribes for good luck and protection from troubles (Kharinskiy, 1994).

Changes in understanding of the functional purpose of the majority of the Baikal coast fortresses required some changes in the term used to denote them. For this reason, the term "fortress" began to be used in square quotes to emphasize the conventional nature of the term. Further studies of the purpose of the Ciabaika- lian "fortresses" and the term used to describe their functional purpose took place in the early $2000-\mathrm{s}$, when the term of sanctuary fortress was introduced (Kharinskiy, 2002c: 117).

At the moment, one of the best studied sanctuary fortresses of the Ciabaikalia is Baikalskoe-1. It was discovered in 1901 by A.A. Korotnev (Korotnev, 1901: 36), and was later visited by a number of researchers (Lotsiia..., 1903: 103; Svinin, 1970: 214; Tivanenko, 1990: 86). The first excavations at the site were carried out in 1986 by A.V. Kharinskiy (Abdulov et al., 1988). As a result of the 7 years' research it was found that Baikalskoe-1 went through several stages of development, causing some significant changes to the appearance of the site. The main share of the archaeological material found at the site date back to the $1^{\text {st }}$ millennium AD. Along with that, some of the findings belong to the $2^{\text {nd }}-1^{\text {st }}$ millennia $\mathrm{BC}$. They are the earliest evidences of the presence of the ancient population in the Baikal coast cape, where later an earth mound and a dyke were arranged, making up the contemporary image of the archaeological site.

Perhaps, the $2^{\text {nd }}-1^{\text {st }}$ millennia $\mathrm{BC}$ were the period when the idea of Baikalskoe-1 rock site as a place of contact with the sacred power was developed. The analysis of archaeological materials of the time will provide a more detailed reconstruction of the process of development of the spiritual world outlook of the population of the north Baikal cost in the Early Metal Age.

\section{Structure}

Baikalskoe-1 sanctuary fortress is located in Severo-Baykalsky District of Buryatia, $620 \mathrm{~m}$ to the east from Baikalskoe Village, in the south part of Cape Ludar, on the cusp-like rock site standing 71-81 $\mathrm{m}$ above Lake Baikal level (Fig. 1). In the south, east and south-west the sanctuary fortress is limited with a cliff going down to Baikal (Fig. 2), and in the north and north-west it is surrounded with a dyke and a rock mound.

The height of the site where the sanctuary fortress is located is descending towards the north; the gradient angle is $12^{\circ}$. The site is covered with grass; there are several middle-height larches. $30-35 \mathrm{~m}$ to the north and north-west 


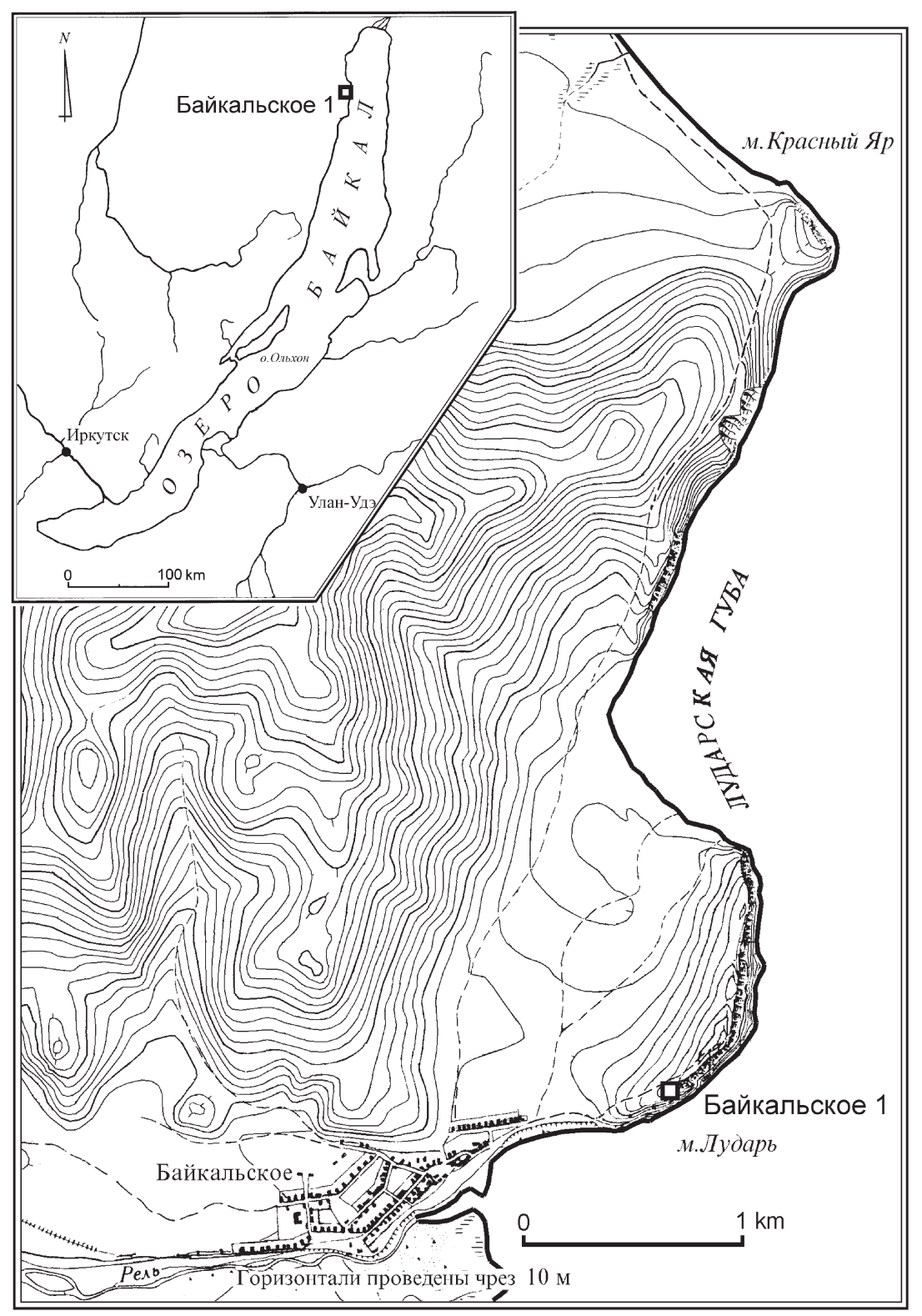

Fig. 1. Baikalskoe-1 sanctuary fortress location map

from the dyke, down the slope, the forest begins. In the west and south-west from the archaeological site, there is an open steep slope gradually merging into a $20-21 \mathrm{~m}$ terrace that stretches in the west to the Rel' river. To the north-west from the site, there is a treeless dell, across which another cusp-like rock site with Baikalskoe-2 sanctuary fortress is located. The cliff forming the border of Baikalskoe-1 in the south, east, and south-west, in the upper part forms several little platforms $0.5-1.0 \mathrm{~m}$ wide.

An earth mound and a dyke divide the site territory into two parts, the inner and the outer one (Fig. 3). The first one ends in a cliff in the south, east and south-west; in the north-west, it is limited with a dyke and an earth mound, with the dimensions of the inner part of the sanctuary fortress being $31 \times 46 \mathrm{~m}$. South-east from 




Fig. 2. Baikalskoe-1, view from the south

the major earth mound, 9-20 $\mathrm{m}$ away, there is a series of elongated earth grooves reminding of a small dyke divided with lanes. Between the series of grooves and the major earth mound, there is a wall made of vertically installed big stones. The earth grooves and the stone wall divide the inner part of the sanctuary fortress into the three zones described below.

Zone I. A natural bench, located in the south-east part of the sanctuary fortress. Its height is gradually decreasing from the southwest ( $81 \mathrm{~m}$ above the Baikal level) to the northeast $(79.5 \mathrm{~m})$. The bench stretches from SWW to NEE for $30 \mathrm{~m}$, and from NNW to SSE for $10 \mathrm{~m}$. It is oval-shaped; from the south and the south-east, it is limited with a cliff. Along the north-western edge, the edge is laden with a series of stones. They are especially prominent in the western part of the site.

By the foot of the bench, there are five earth grooves. Their configuration is not clear. The average width of the grooves is $1.0-1.5 \mathrm{~m}$. The first, the south-westernmost groove of about $3 \mathrm{~m}$ long is located $6 \mathrm{~m}$ away from the edge of the cliff. One meter away from groove No. 1 , there is groove No. 2, which is about $4 \mathrm{~m}$ long. The distance between grooves No. 2 and
No. 3 is $3 \mathrm{~m}$. Groove No. 3 is around $2.5 \mathrm{~m}$ long. One meter away, there is groove No. 4 with vague borders; perhaps, it was connected to groove No. 3. The approximate length of groove No. 4 is 2 meters. The distance between grooves No. 4 and No. 5 is $1.5 \mathrm{~m}$. Groove No. 5 is around $7 \mathrm{~m}$ long. It is located $3 \mathrm{~m}$ away from the cliff.

Perhaps, the gaps between grooves No. 1 and 2, 2 and 3,4 and 5 are passageways. The sides of the central passageway are paved with stones. In some cases, the earth grooves were also paved with stones on the outside. The largest stones are found in the north-west from grooves No. 3 and 4. The elevation difference between the external edge of the grooves and the bench shoulder is $1.5-2.0 \mathrm{~m}$.

Zone 2. The site framed by the artificial earth grooves in the south-east and a wall of vertically fixed stones in the north-west is titled Zone 2. The south-western and the north-eastern ends of the zone reach the cliff. The length of the zone is $40 \mathrm{~m}$; the width in the south-west is around $14 \mathrm{~m}$, and in the north-east it is about $6 \mathrm{~m}$. The site rises by $77.5-80.0 \mathrm{~m}$ above the Baikal level. The average slope gradient angle is $12^{\circ}$. The vertical stone wall survived best in 


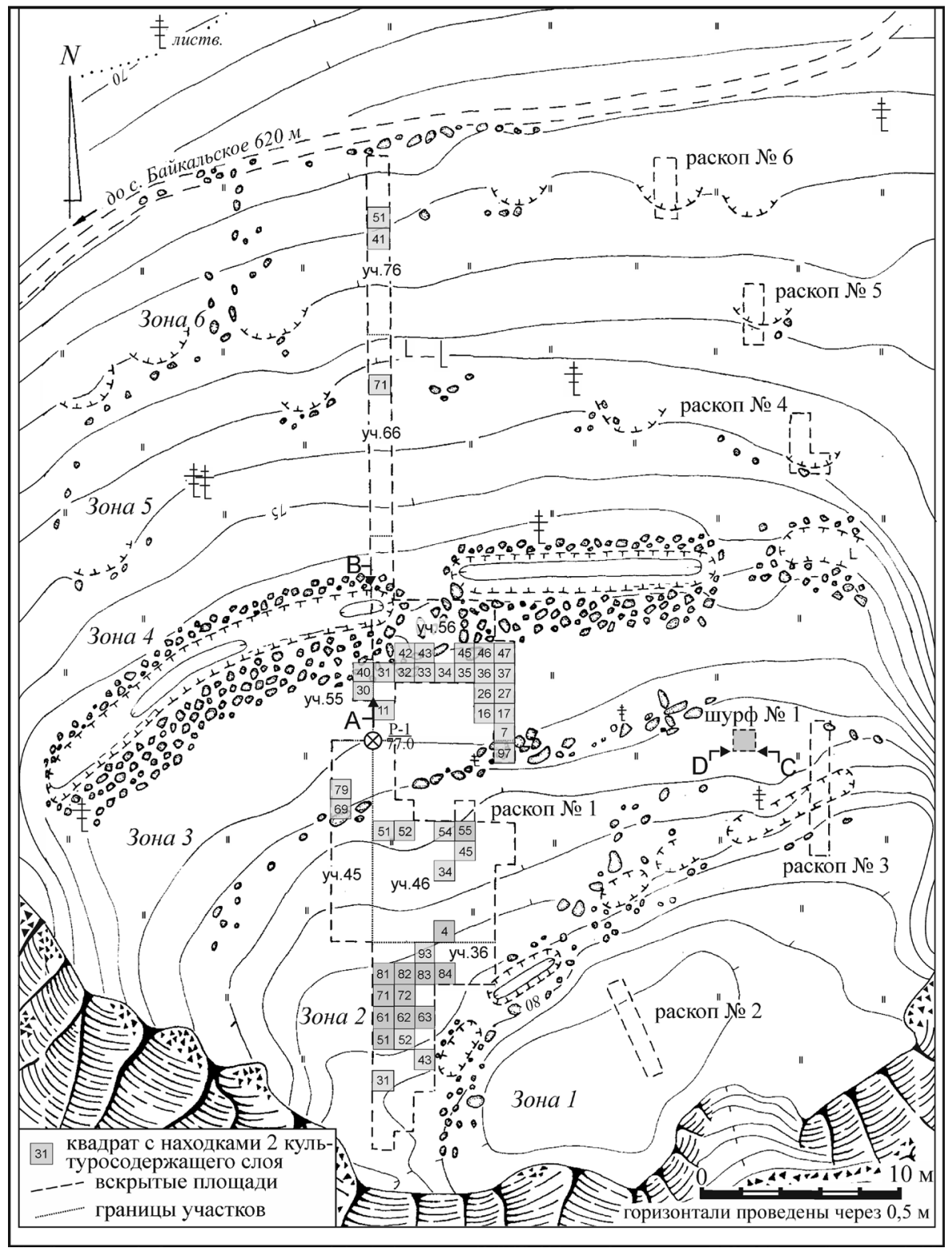

Fig. 3. Baikalskoe-1 sanctuary fortress layout

its north-eastern part. In the south-west, the major part of the stones has collapsed. The current measurable length of the wall is around $27 \mathrm{~m}$. The length of its constituent stones reaches $1.2 \mathrm{~m}$, with the maximum height of $0.8 \mathrm{~m}$. The major part of the wall is made of the stones installed in one line.

Zone 3. The area between the stone wall and the main earth mound comprises Zone 3. It stretches from the north-east to the south-west for about $45 \mathrm{~m}$. In the north-eastern part, it is $4 \mathrm{~m}$ wide, and in the south-west part it is $8 \mathrm{~m}$ wide. The elevation of the area is 76.6-77.4 m; its surface is quite smooth in all the directions.

The main earth mound is made of stones and some loose sediment. There are three clear passageways, directed, with a little deviation, to the western, central and eastern passage- 
ways in the artificial earth grooves of Zone 1 . The passageways divide the earth mound into three areas: a) the western area between the western and the central passageways; b) the central area between the eastern and the central passageways; c) the eastern area between the eastern passageway and the cliff.

The rockfill outside the dyke is also divided into three parts. Its length is equal to that of the dyke; the width is 2 meters. The elevation difference between the dyke bottom and the rockfill top is $0.35 \mathrm{~m}$.

In the north, the outer part of the site is limited with a wall made of vertically installed line of rocks. The rock wall is located $22 \mathrm{~m}$ to the north from the main dyke. The currently measurable length of the wall is $21 \mathrm{~m}$.

Between the main dyke and the stone wall in the north from it, there are two rows of artificial round pens, the biggest of them being $2 \times 4 \mathrm{~m}$. The southern shoulder of the pens is often reinforced with some stones. The pen rows are arranged radially with respect to the dyke. The arrangement of the pens divides the outer part of the site into three zones.

Zone 4. The terrace-like slope lying between the outer rockfill of the dyke and the first row of the artificial pens lies at the elevation of 74.2-75.6 m. Both of its sides stretch to the cliff. At the edges, its width is $2-3 \mathrm{~m}$; in the middle, it is around $9 \mathrm{~m}$.

Zone 5. The terrace-like slope lying at the elevation of 72.6-74.6 $\mathrm{m}$ between the first and the second rows of the artificial pens. In the western part, its width is $3 \mathrm{~m}$; in the eastern, it is $12 \mathrm{~m}$.

The first (southern) and the second (northern) rows have seven pens each. Between the rows of the pens in the eastern part of Zone 5, there is a separately located artificial pen.

Zone 6. The terrace-like slope lying at the elevation of $71.5-73 \mathrm{~m}$. This zone includes the territory between the northern row of the round pens and the stone wall. In the western part, the zone is $8 \mathrm{~m}$ wide; in the eastern, it is $3 \mathrm{~m}$.

\section{Digging procedure}

The diggings in Baikalskoe-1 commenced in 1986. For the entire supposed area of the site, it was decided to establish a unified artefact lo- calization system. The sanctuary fortress territory was broken into plots of $10 \times 10 \mathrm{~m}$, with their sides oriented to the four cardinal directions. One hundred plots make up a sector of $100 \times 100 \mathrm{~m}$, with the centre being the reference point P-I (elevation $77 \mathrm{~m}$ above the Baikal level on 10.07.1990). In their turns, the plots were broken into squares of $1 x 1 \mathrm{~m}$. Just like the areas, they were numerated first along the $\mathrm{X}$, and then the $\mathrm{Y}$ axis, i.e. from the west to the east and from the south to the north.

During 7 years of works (from 1986 to 1992), the area of 181 square meters was unearthed. In different parts of the sites, 6 excavation sites and one exploring shaft were made. The largest excavation site is No. 1. It crosses five zones of the site from the south to the north, covering plots $36,45,46,55,56,66$, and 76. The area of the excavation site was 158 sq. m. (Fig. 3).

The excavation helped to formulate the structural peculiarities of the earth mound and the dyke of the sanctuary fortress; to record the stratigraphy of the loose sediments and the archaeological material lying underneath. Excavations No. 2 (5 sq.m.) and No. 3 (7 sq.m.) revealed the data that determine the structural and stratigraphic features of Zone 1 of the sanctuary fortress. The excavations No. 4 (4 sq.m.), No. 5 and No. 6 (3 sq.m. each) were used to study the artificial pens located at the external side of Baikalskoe-1.

The excavation sites were unearthed by horizontal removal of the loose sediments, with the layer-wise registration of the revealed archaeological material, natural and artificial formations. In a part of the excavation area, two culture-bearing strata were found. The upper culture-bearing stratum ( $1^{\text {st }}$ c.b.s. $)$ included findings dating back to the $1^{\text {st }}$ millennium A.D., and the lower culture-bearing stratum ( $2^{\text {nd }}$ c.b.s.) included materials of the $2^{\text {nd }}-1^{\text {st }}$ millennia B.C. In order to determine the specificity of the $1^{\text {st }}$ and the $2^{\text {nd }}$ culture-bearing strata, a shaft of $1 \times 1 \mathrm{~m}$ was made in the eastern part of the sanctuary fortress (Zone 2).

\section{Stratigraphy}

The stratigraphic section drawn through the centre of the inner part of the sanctuary for- 
tress from the north southward and belonging to the excavation site No. 1, has the following features (vertically down) (Fig. 4, 1).

1. Topsoil: $0.03-0.05 \mathrm{~m}$.

2. Grey clay sand: $0.05-0.32 \mathrm{~m}$.

3. Brown clay sand with separate stones sized from $3 \times 7$ to $20 \times 30 \mathrm{~cm}: 0.04-0.12 \mathrm{~m}$.

4. Yellowish-grey clay sand with scree, chip stone, and few rolled pebbles sized from $4 \mathrm{x} 8$ to $35 \mathrm{x} 50 \mathrm{~cm}$ : $0.05-0.55 \mathrm{~m}$.

5. Light brown clay sand with rock chips and poorly rolled pebbles sized from $3 \times 6$ to 20x60 cm: $0-0.10 \mathrm{~m}$.

6. Brown rock chips with gravel and stones: unearthed by $0.35 \mathrm{~m}$.

The greatest thickness of the geological layer 2 was found in Zone 2 of the sanctuary fortress, where it constituted $25-32 \mathrm{~cm}$. In Zone 3 , the layer is $5-14 \mathrm{~cm}$ thick. At the borderline between Zones 2 and 3, between the layers of the grey and brown clay sand, some ash and coal lenses with the thickness reaching $5 \mathrm{~cm}$ were found. The brown clay sand thickness in Zones 2 and 3 varies from 5 to $8 \mathrm{~cm}$. At the foundation of the layer, there are several cryogenic cracks with the depth reaching $40 \mathrm{~cm}$ and the maximum width of $60 \mathrm{~cm}$. The light brown clay sand layer is only found in the southern and the central parts of Zone 2 .

Starting from the middle part of Zone 3, the stratigraphic situation gets more complex. Between the $2^{\text {nd }}$ and the $3^{\text {rd }}$ geological layers, there appears a dark-grey clay sand streak 2-8 $\mathrm{cm}$ thick, saturated with coal. In some places, the streak is crossed by light-grey sand lenses up to $3 \mathrm{~cm}$ thick.

The main earth mound of the sanctuary fortress was made up of the dark-grey clay sand coal-saturated layer. The time of its existence can be divided into three stages: 1) before the log structure was made; 2) during the log structure existence. These construction stages are clearly distinctive in the north-eastern side of the western earth mound area. There are some charred remains of logs found between the earth mound stones.

The main Baikalskoe-1 earth mound is made of stones with the dimensions varying from $5 \times 6$ to $30 \times 35 \mathrm{~cm}$. The space between the stones is filled with a disintegrated mass of pre- dominantly clay-sand nature, with some light grey sand lenses. At the first stage of its existence, the currently measurable earth mound height was $40 \mathrm{~cm}$.

The coal streak formed after the log structure had burned down looks differently in different areas of the earth mound. The greatest thickness is found to the south from the log structure, reaching $7-13 \mathrm{~cm}$. Further to the west, the streak thickness decreases. In square 40 plot 55 it is hardly distinctive. In the northern part of Zone 3, the coal streak overlies the grey clay sand layer.

The sanctuary fortress dyke was made in the grey clay sand layer. In the ancient times, the dyke was $2 \mathrm{~m}$ wide and $0.6 \mathrm{~m}$ deep. The southern wall of the dyke is steep, and the northern is gently slanting. The dyke penetrates into the brown clay sand and the yellow-grey clay sand layers by $30 \mathrm{~cm}$. At the present moment, the dyke is filled with loose sediments and stones that had rolled down its edge by $50 \mathrm{~cm}$. The bottom part of the dyke is filled with grey clay sand, and the upper is filled with dark-grey humous clay sand. The bottom of the dyke is rounded.

To the north from the dyke, there is a predominantly single layer rockfill. The dimensions of the rocks vary from $12-15$ to $25 \times 40 \mathrm{~cm}$. They are taken from the bottom of the grey clay sand layer.

In the process of excavations carried out at the sanctuary fortress, two culture-bearing strata were revealed. The first lies in the topsoil and grey clay sand contact area as well as in the grey clay sand layer. The bottom culture-bearing stratum belongs to the grey and brown clay sand contact and the upper part of the brown clay sand layer. From the stratigraphy perspective, the second culture-bearing stratum is not always clearly distinctive from the first. They are only divided with coal streaks and lenses in Zone 4 only. The archaeological material belonging to the $2^{\text {nd }}$ culture-bearing stratum lies in the site territory in four areas (Fig. 3). The first one, the south area, is located in the southern part of Zone 2. Here, the second culture-bearing stratum material is represented by individual findings spotted in different squares of plots 36 and 46 . The second area is localized 


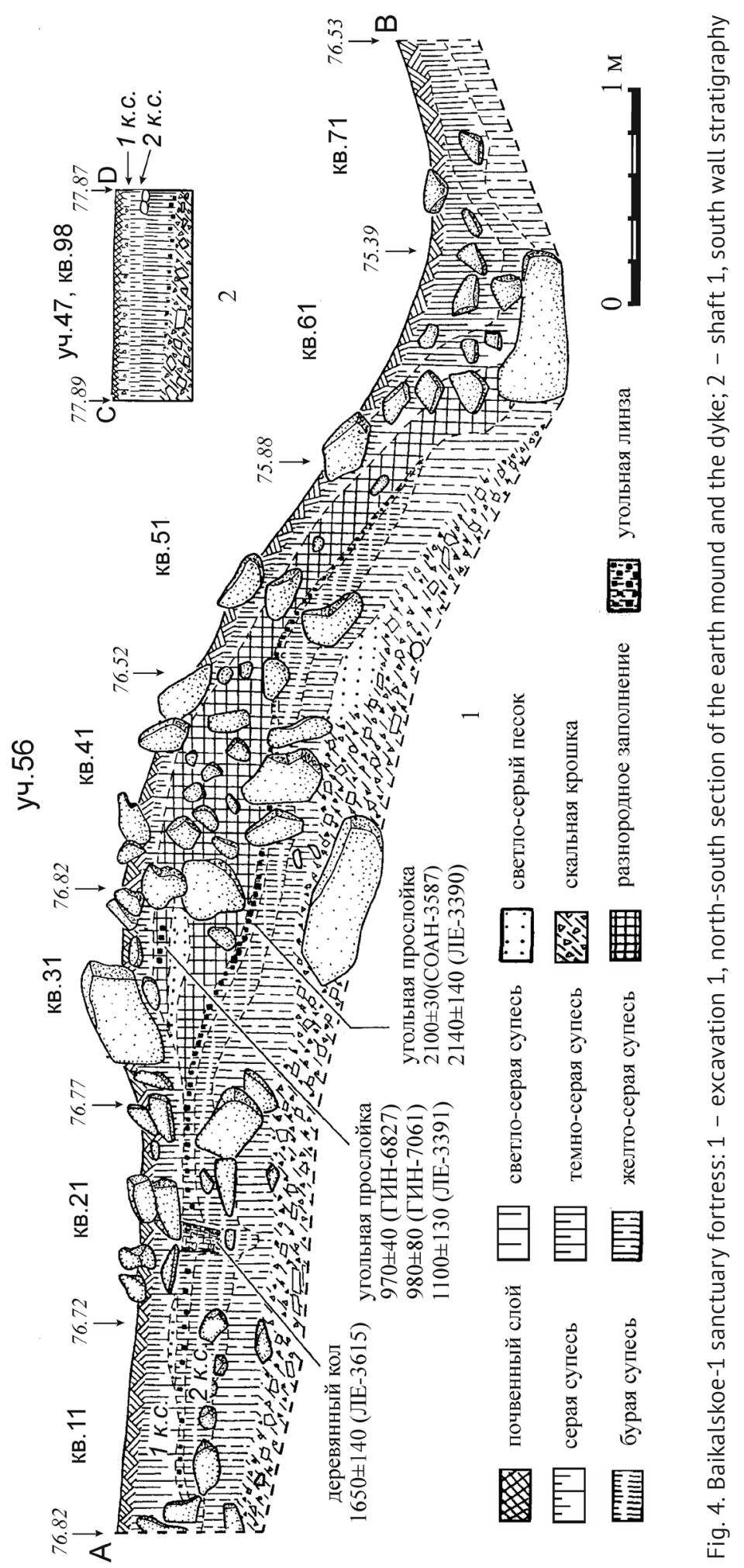


on the borderline between Zones 2 and 3; it includes some stone artefacts, production wastes and ceramic kitchenware fragments. The third area belongs to Zone 3, plots 55 and 56. The findings are concentrated in front of the central passageway of the sanctuary fortress and by the foot of the earth mound. Besides the stone and ceramic artefacts, a great number of burnt fragmented animal bones are found. The fourth area is located in Zones 5 and 6, represented by a small number of findings.

Typologically, the archaeological material of the second culture-bearing stratum is clearly different from the findings of the first one; for this reason, distinguishing the findings of the upper and the lower culture-bearing strata was not a challenge for the researchers.

\section{Findings}

The artefacts found in the second culture-bearing stratum are classified into stone items, ceramics and ivory. The stone items are represented by three categories of tools: arrowheads (sharp pointers), scrapers and knives.

Arrowheads. In the second culture-bearing stratum of Baikalskoe-1, one quartzite (Fig. 4, 3) and six silicon (Fig. 4, 1, 2, 4-7) arrowheads were found. The arrowheads are sub-triangular shaped, with slightly convex edges. Based on the stem line peculiarities, the arrowheads can be classified into four types (Bazaliyskiy, 2010).

Concaved stem and symmetric body. Two arrowheads. The silicon arrowhead is treated on both sides (Fig. 4, 1). It is $3.3 \mathrm{~cm}$ long, $1.5 \mathrm{~cm}$ wide, stem width $1.5 \mathrm{~cm}$, stem concave height $0.2 \mathrm{~cm}$. The quartzite arrowhead has treated edges on both sides (Fig. 4, 3). It is 3 $\mathrm{cm}$ long, $1.5 \mathrm{~cm}$ wide, stem width $1.1 \mathrm{~cm}$, stem concave height $0.2 \mathrm{~cm}$.

Concaved stem and asymmetric body. One arrowhead. The arrowhead has treated edges on both sides (Fig. 4, 2). It is $3.4 \mathrm{~cm}$ long, $1.6 \mathrm{~cm}$ wide, stem width $1.3 \mathrm{~cm}$, stem concave height $0.3 \mathrm{~cm}$, one spur is longer than the other by $0.2 \mathrm{~cm}$.

Straight stem line and symmetric body. One arrowhead. The arrowhead with a broken blade and treated edges on both sides (Fig. 4, 7). Its maximum width equals to the stem width.
The approximate arrowhead height is $2.3 \mathrm{~cm}$, with the width of $1.3 \mathrm{~cm}$.

Slightly concaved stem and symmetric body. The type is represented by one arrowhead, which morphologically lies in between the straight stem and the concaved stem arrowheads, but features its own, individual metric characteristics. This arrowhead is treated completely on both sides (Fig. 4, 1). Its edge curvature is less prominent than that of the other arrowheads; the maximum width equals the stem width. The arrowhead shape is close to triangle. It is $4.6 \mathrm{~cm}$ long, $2 \mathrm{~cm}$ wide; the stem width is $2 \mathrm{~cm}$, and the stem concave height is $0.1 \mathrm{~cm}$.

The stems of two arrowheads are not definable as a result of damage. The current length of the first is $3.6 \mathrm{~cm}$, with the width being 1.8 $\mathrm{cm}$. On one side, it is treated completely, on the other side, only the edges are treated (Fig. 4, 5). The survived length of the second arrowhead is $2 \mathrm{~cm}$, with the width $1.7 \mathrm{~cm}$. Both sides are treated by shearing (Fig. 4, 6).

Scrapers. Four intact and one broken scrapers were found. These are simple end scrapers made of flakes. The stem and blade peculiarities determine three types among them.

Acuminated oval scrapers. Two scrapers. The blade is oval shaped, roughly treated by shearing. The stem is acuminated. The small width $(0.7 \mathrm{~cm})$ is measured closer to the blade. Both faces of the scraper are treated all along the surface. The length of the scraper is 4.2 $\mathrm{cm}$, the width is $2 \mathrm{~cm}$, the stem width is 0.7 $\mathrm{cm}$ (Fig. 5, 8). Presumably, the broken blade scraper belongs to the same type, though, with regard to its morphological peculiarities, it may be positioned between the acuminated oval and trapezium-shaped ones. The ventral face of the scraper is not specifically treated. On the dorsal face, the edge is treated by shearing. The scraper stem width is $0.7 \mathrm{~cm}$ (Fig. 5, 12).

Trapezium-shaped scrapers. Two scrapers of this type have been found. Both have a slightly curved blade treated by shearing. The bigger scraper's stem is broad angle-shaped. The greatest thickness $(1.3 \mathrm{~cm})$ was measured closer to the blade. Scraper with treated dorsal face. On the ventral face, the left margin is 

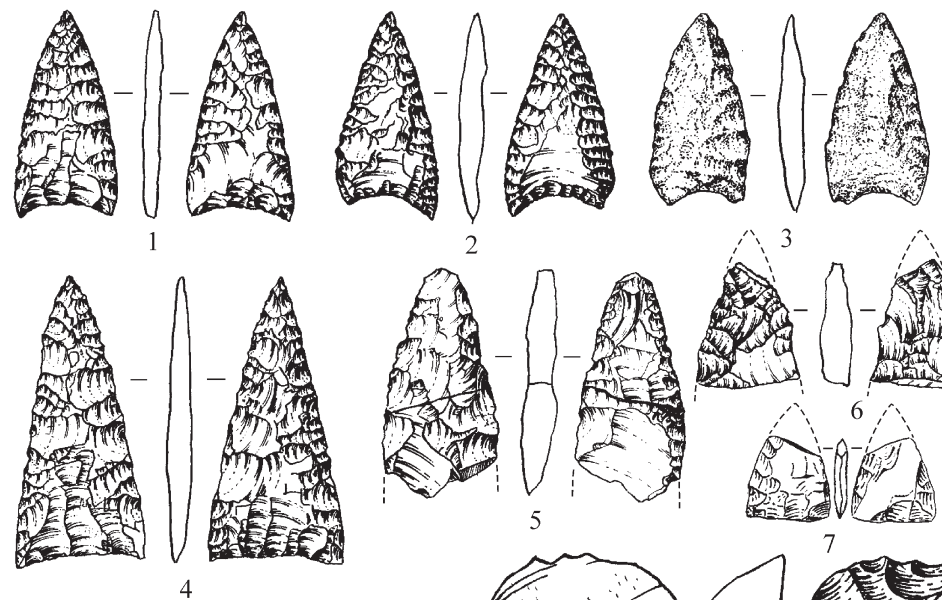

2


9

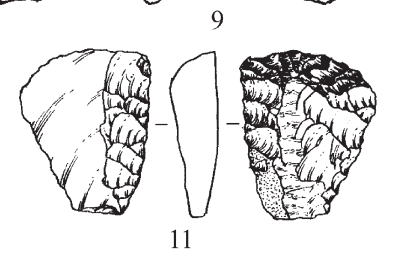

10

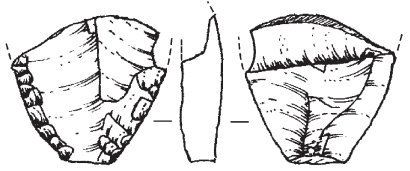

12

Fig. 5. Baikalskoe-1, $2^{\text {nd }}$ culture-bearing stratum, stone items: 1 -pl. 56, sq. 43; 2 -pl. 36, sq. 84; 3 -pl. 56, sq. 36 ; 4 -pl. 36, sq. 82; 5,8 -pl. 46, sq. 45; 6 -pl. 36, sq. 43;

7 - shaft $1 ; 9$-pl. 56 , sq. $45 ; 10$-pl. 56, sq. 31; 11 - pl.56, sq. 32; 12 -pl. 45 , sq. 69

partially treated with deep shear. The scraper is $5.1 \mathrm{~cm}$ long, the blade width is $3 \mathrm{~cm}$, the stem width is $1.7 \mathrm{~cm}$ (Fig. 5, 9).

The second scraper has a straight stem. The greatest thickness $(0.7 \mathrm{~cm})$ is registered closer to the blade. The scraper has a completely treated dorsal face. On the ventral face, the left margin has the edges treated by shearing. The scraper length is $2.5 \mathrm{~cm}$, the blade width is $2.2 \mathrm{~cm}$, the stem width is $1 \mathrm{~cm}$ (Fig. 5, 11).

Pentagonal scrapers. One scraper. The blade is slightly concaved and treated with slanted shearing. The stem is triangular. The greatest thickness $(0.8 \mathrm{~cm})$ is registered closer to the stem. The stem is triangular. The blade is treated by shearing on both faces. The scraper length is $3.3 \mathrm{~cm}$, the blade width is $3.4 \mathrm{~cm}$ (Fig. 5, 10).

Cleavage knife. One cleavage knife was found. It is made of a large silicon cleavage face $1.5 \mathrm{~cm}$ thick (Fig. 6, 1). The rounded blade is made on the right margin of the item, all along its length. The edge treatment is seen on both faces. The knife blade is symmetrical on both 


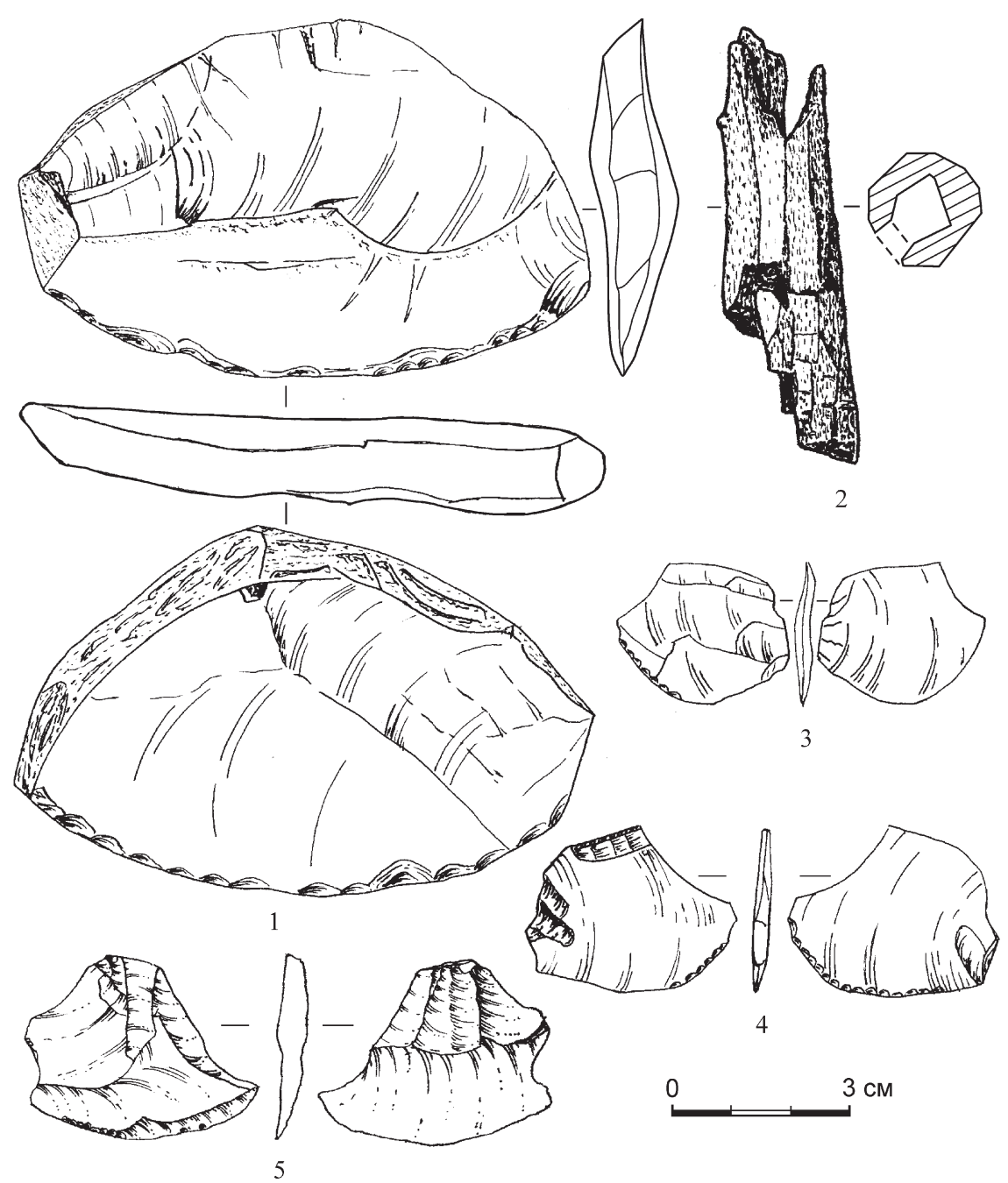

Fig. 6. Baikalskoe-1, $2^{\text {nd }}$ culture-bearing stratum, stone items: 1 -pl. 36, sq. 82; 2 -pl. 56, sq. 36; 3 -pl. 56, sq. 46; 4 -pl. 46, sq. 54; 5 -pl. 46, sq. 52

sides. The knife length is $9.3 \mathrm{~cm}$, the width is $5.8 \mathrm{~cm}$.

Flake knives. Three flake knives were found. The blade was not sharpened additionally by shearing. The cutting edge, or blade, formed as the flake was chipped off. Some shock shearing occurred on the blade in the process of use. In the first knife (Fig. 6, 3) the concaved left margin of the flake served as a blade. The shock shearing occurred on the dorsal face, closer to the distal end. The knife length is $2.8 \mathrm{~cm}$, the width is $2.3 \mathrm{~cm}$.
The second knife is $3.5 \mathrm{~cm}$ long, with the width $2.8 \mathrm{~cm}$ (Fig. 6, 4). The concaved right margin of the flake served as a blade. Some shock shear occurred on the dorsal face, closer to the distal end, and on the ventral face, almost all along its length. On the dorsal face of the left margin some edge shearing was made and the traces of the rubbed shock shearing are found. The shearing was directed to the distal end, but after that part of the knife had broken off, the right margin served for cutting.

In the third knife, the blade was the distal end of the flake (Fig. 6, 5). In the middle part of 


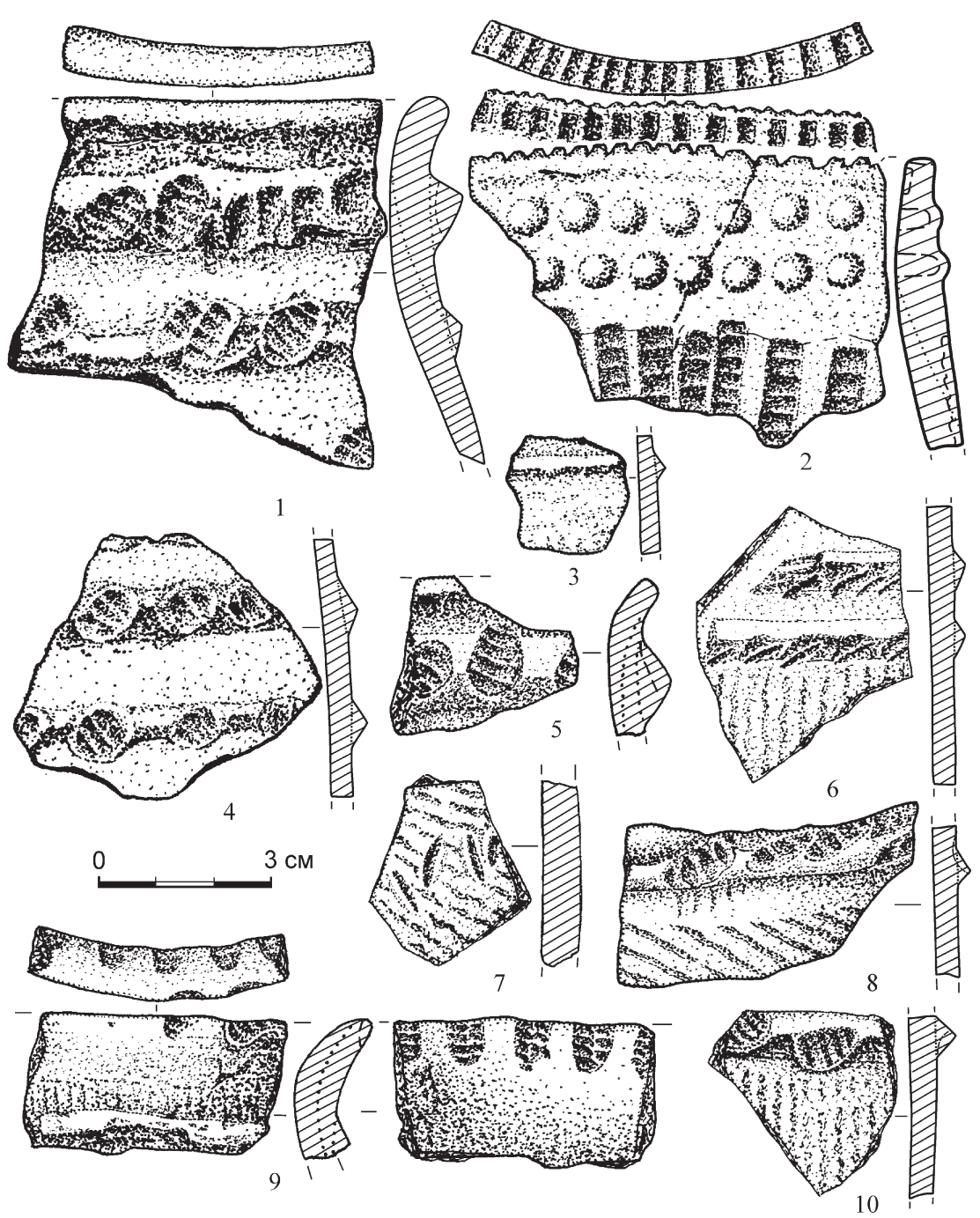

Fig. 7. Baikalskoe-1, $2^{\text {nd }}$ culture-bearing stratum, stone items: 1, 4 -pl.56, sq. 36; 2 - pl. 56, sq. 37; 3 -pl. 56, sq. 47; 5 -pl. 56. sq.7; 6 -pl. 56, sq. $46 ; 7$-pl. 46, sq. 54; 8 -pl. 46 , sq. $97 ; 9$ - pl. 55 sq. $40 ; 10$-pl. 66 , sq. 71

the blade, on the dorsal face side, some shock shearing is found. The blade is concaved, 3.3 $\mathrm{cm}$ long. The knife width is $3 \mathrm{~cm}$.

Ceramic pottery. The pottery found in the second culture-bearing stratum is represented by vessels of two types: the Tyshkine (Senogda) type (140 fragments of 5-7 pots) and Glazkov type (4 fragments of one pot).

The Glazkov type vessel (Fig. 7, 2) has smooth walls with a straight crown of $5 \mathrm{~mm}$, slightly opened outward. The mouth of the pot is formed by attachment of a clay stripe to the upper part of the body on the outer side. The body and mouth jointing area is around 2.6 $\mathrm{cm}$ wide. The mouth height is $2.3 \mathrm{~cm}$, with the foundation thickness $9 \mathrm{~mm}$. The pot is decorated with a pressed-on ornament. The crown on top is divided with cross-over vertical pressings of 2-3 $\mathrm{mm}$ wide located $2-3 \mathrm{~mm}$ away from each other. On the inner side of the pot, $2 \mathrm{~mm}$ from the crown edge, there is another row of the pressed-on ornament made by the edge of a spatula. The height of each pressing is $5 \mathrm{~mm}$, the width is $3 \mathrm{~mm}$. The ornament 
was pressed on from left to right with the right hand. Outside, the middle and the lower part of the pot mouth is ornamented with rows of "pearls" with the diameter of $5 \mathrm{~mm}$. The upper row of the pressed-on ornament is located $8 \mathrm{~mm}$ away from the crown edge; the second row of the "pearls" is $3 \mathrm{~mm}$ below the upper one. The distance between the "pearls" in the row is $2-3 \mathrm{~mm}$. The upper part of the pot body is decorated with the vertical pressed-on ornaments made by a spatula. The ornament was made with the edge of the spatula, at an angle to the pot surface (press-on stamping). The distance between the pressings in one row was 3-4 $\mathrm{mm}$. The spatula width was $7 \mathrm{~mm}$. The distance between the pressed-on ornament rows is $2-6 \mathrm{~mm}$.

On their walls, the Tyshkine (Senogda) pots have impressions of a rope, smoothed out near the crown area. The pot mouths are decorated with oval crowns deflected outward (Fig. 7, 1, 5, 9). Their width is 5-7 $\mathrm{mm}$. The pot mouth is shaped with a clay stripe attached to the upper part of the pot body from the outer side. The body and mouth jointing area is approximately $2.5 \mathrm{~cm}$. The mouth height is 3.5 $\mathrm{cm}$, its foundation thickness is $7 \mathrm{~mm}$.

The ornaments on the pots were made by pressing and attachment. The pressed-on ornaments include the oval crossed-over pattern (the larva pattern), finger and nail impressions. Among the attached ornaments, there are wide and narrow attached rolls with triangular section. Generally, in the bottom part of the pot mouth, there would be wider rolls $0.6-0.7 \mathrm{~mm}$ thick and $1.5-1.8 \mathrm{~cm}$ wide (Fig. 7, 1, 5). At the same time, some narrower ones $0.4 \mathrm{~cm}$ thick and $0.9 \mathrm{~cm}$ wide are also found (Fig. 7, 9). The pot body was usually decorated with thinner rolls, $0.3-0.4 \mathrm{~cm}$ thick and $0.7-1.0 \mathrm{~cm}$ wide (Fig. 7, 1, 3, 4, 6, 8, 10). The major part of the rolls is ornamented with the oval crossed over patterns (the larva pattern) or deformed with nail impressions (Fig. 7,6), even though some non-crossed rolls are also found (Fig. 7, 3, 9).

The oval crossed-over patterns (the larva pattern) decorate the pot crown on the inner and the outer sides (Fig. 7, 9), arranged across. They also cross over the rolls decorating the pot body and mouth at an angle (Fig. 7, 1, 4, 5, 8,
10). The sizes of the oval crossed over pressedin patterns vary from $0.5 \times 1.3 \mathrm{~cm}$ to $0.9 \times 1.5 \mathrm{~cm}$. Their size depends on the depth of the impression and the profile of the decorated surface. The number of the crossing cells in every oval impression varies from 3 to 5 .

The rolls were also shaped by means of slight finger squeezes. The left hand thumb would be placed below, and the pointer on top. The pointer would leave the finger cushion impression on the clay surface, and the thumb would leave the impression of its nail (Fig. 7, 6). The pot body surface was also decorated with nail impressions. The thumb nail would leave an impression on the left, and the pointer nail on the right, slanted against each other at an angle (Fig. 7, 7).

Among ivory, there is one item of unknown purpose. Since only fragments are found, the initial appearance of the object cannot be reproduced. The remaining part of the item is a cylindrical polygon, hollow inside (Fig. 6, 2). One of the ends of the item is hewed. The item was annealed, just like all other ivory items found in the second culture-bearing stratum.

\section{Discussion}

During excavations at Baikalskoe-1 site, no artificial structures that could relate to the second culture-bearing stratum formation period were found. All protective structures, such as earth mounds, dykes, and walls, were built only in the $1^{\text {st }}$ millennium AD. They were fitted in the existing terrain, highlighting the natural surface of the cusp-like area.

The oldest items found in Baikalskoe-1 sanctuary fortress were detected at the inner side of the central passageway, at the bottom of the brown clay sand layer, $20 \mathrm{~cm}$ deep. They are represented by quartzite flakes, a quartzite arrowhead and fragments of a pot with the upper part decorated with the two rows of "pearls" with the vertical rows of the stepping-back spatula impressions underneath (Glazkov type pot).

On the north-west coast of Lake Baikal, the archaeological sites with the Glazkov type pottery belong to the Bronze age, dating back to the $2^{\text {nd }}-$ mid $1^{\text {st }}$ millennium BC. In this part of the Baikal coast, they replace the older 
sites with the North-Baikal type pottery (Kharinskiy, Emel'ianova, Rykov, 2009: 126). The Glazkov type pot from Baikalskoe-1 is decorated with pearls and the rows of the vertical impressions of the stepping-back spatula, made by carrying the stamp across the pot, making regular impressions on its surface. A similar Glazkov type pot decoration technique used in the north coast of Lake Baikal may be described as one of the earliest ones, presumably belonging to the $2^{\text {nd }}$ millennium $\mathrm{BC}$. On the Glazkov pots belonging to the $1^{\text {st }}$ millennium $\mathrm{BC}$, there are no decorations made by carrying the stamp across the pot with regular impressions of the stamp against the surface. In that period, it was more typical to arrange the spatula impressions with the equal gaps between them, without connecting them with a stamp carried over across the entire pot body. The age of the Glazkov type pottery site is also proven by the other artefacts made of quartzite. This material was also used for making tools on the north-western coast of Lake Baikal predominantly in the early Bronze age, associated with the sites where the North-Baikal-type pottery is represented (Emel'ianova, Kharinskiy, 2008; Emel'ianova, 2010).

The fragments of the Glazkov type pot and the quartzite artefacts are localized in a spot of $2 \times 3 \mathrm{~m}$ in the north-western part of excavation site No. 1 (plot 56, squares 26, 27, 36, 37) in the brown clay sand layer. In the same geological layer, but predominantly in its superface, there are some fragments of the Tyshkine (Senogda) type pots together with the silicon items. There are no free layers between them. By the eastern wall of the excavation site (squares 27 and 37 ), the quartzite flakes are found in the yellow-grey clay sand stratum located underneath the brown clay sand layer. Between the two layers, there is a minor coal lining.

The archaeological findings of the Tyshkine (Senogda) pottery and silicon items are found in Zones 2, 3, 5 and 6 of the sanctuary fortress. They lie in the grey clay sand stratum $10-20 \mathrm{~cm}$ deep. The greatest concentration of the archaeological findings is registered by the internal side of the earth mound (plot 56, squares 32-37, 42-47). In each of squares 32-34, 43 over 20 silicon flakes are found, just like in shaft 1. It makes the impression that this part of the sanctuary fortress was used for the stone tool production, even though all around the territory of Baikalskoe-1 not a single nucleus was found. In other parts of the site, findings belonging to the $2^{\text {nd }}$ culture-bearing stratum are rare, represented, most frequently, with 1-3 flakes, as in the internal part of Baikalskoe-1, or 1-2 ceramic fragments as in its outer part. It is not impossible that they happened to be in Zone 2, 5 and 6 by accident.

On the other hand, the presence of occasional stone items such as arrowheads, scrapers, and flake knives in Zone 2 of the sanctuary fortress lets us suppose that they could have been brought there on purpose as offerings to some sacred powers. At the same time, in the most elevated area of the sanctuary fortress (Zone 1) no findings belonging to either the first or the second culture-bearing stratum were found, which indicates the special status of this archaeological site, which had been maintained throughout the entire period of its existence. Perhaps, Zone 1 was considered to be a place where the sacred powers could appear, and the presence of people or any items from their world was not preferable. It was associated with the natural rock ledge, prominent in the southern part of the cusp-like site. These natural features of the cusp-like site were the reason why the people, living around Cape $\mathrm{Lu}-$ dar in the second half of the $2^{\text {nd }}-1^{\text {st }}$ millennium $\mathrm{BC}$, selected this place for organizing a sanctuary.

At the first stage of the sanctuary fortress existence, Zone 1 was separated from the underlaying slope where the zone for leaving offerings for the deities was located with some rock formations (upper part of Zone 2 of Baikalskoe-1). Perhaps, during the ritual ceremonies, only the selected representatives of the local community, the "elders" were allowed to enter the area to leave their offerings and to address the deities with prayers. Below, there was a land plot where a large amount of stone item production wastes was found (lower part of Zone 2 and Zone 3 of Baikalskoe-1) along with the annealed fragmented animal bones.

In the area of the site adjacent to the earth mound of the sanctuary fortress, the brown 
clay sand, where the second culture-bearing stratum is detected, is overlaid with a layer of coal. It clearly separates the culture-bearing strata of the site from each other. In front of the passageway, such a coal streak is not found, even though some findings belonging to the second culture-bearing stratum are also present there, including, among others, some annealed bones. Perhaps, in this part of the cusplike area, there were no wooden structures, which would form a coal streak when burned. It is also possible that the coal streak survived only in the part of the site where it was later covered with the collapsed earth mound or the soil and stones slipping down on top of it. Near the passageway, such a coal streak was absent. The coal could have been trampled down and spread around a wider territory, destructing the clear border between the two layers. But even regardless the possible processes of spreading the coal, near the passageway, in the brown clay sand layer where the second culture-bearing stratum is found, a significant amount of ash and annealed bone was found. The fragmentation of the annealed animal bones indicates that they were purposefully laid into the fire for long treatment, which destructed them. Animal bones in such condition are currently found in the sanctuaries of the Cisbaikal Buryats. Annealed animal bones are found on the stone shree altars, where the sacred fire would be made (Kharinskiy, 2002a). The animal carcasses would be cremated, and the smoke was believed to deliver their spirits to the deities. Just like in the second culture-bearing stratum of Baikalskoe-1, small annealed bones and coal would remain on the altar.

The specificity of Baikalskoe-1 as a ritual site, perhaps, was the factor that determined the set of artefacts that would be produced or delivered here in the ancient time. And if an archaeological site with Glazkov type pottery and quartzite artefacts does not look informative enough to make any conclusions, a facility with Tyshkine (Senogda) pottery and silicon items is quite enough to be used for a preliminary analysis.

The stone tools found in the second layer of the sanctuary fortress are quite frequent around the Neolith-Bronze age archaeological sites of the Baikal coast. Such a wide temporal and spatial occurrence of the sub-triangular arrowheads, end scrapers made of laminar flakes and flake knives with untreated blades is not sufficient for the cultural and chronological localization of the entire range of artefacts of the second culture-bearing stratum. From the point of view of their morphological and typological specificity, the ceramic Tyshkine (Senogda) type pottery of Baikalskoe-1 sanctuary fortress may belong to the $6^{\text {th }}\left(5^{\text {th }}\right)-2^{\text {nd }}$ centuries $\mathrm{BC}$ (Kichigin, 2010: 173-178). The entire archaeological site of the second culture-bearing stratum of the sanctuary fortress may belong to that period.

The data of the age of the second culture-bearing stratum collected through the comparative and typological analysis may be clarified with the radiocarbon dating carried out at Baikalskoe-1. Two of the dates are acquired from analysis of the coal streak up to 5 $\mathrm{cm}$ thick, overlying the top of the second culture-bearing stratum of the sanctuary fortress in Zone 3. It is especially visible further to the west from the central passageway, at the foot of the earth mound (Fig. 4). From the coal streak, two radiocarbon dating results are acquired: $2140 \pm 140$ y.a. (LE-3390) and $2100 \pm 30$ y.a. (SOAN-3587). The first date has a larger confidence interval, so it should not be taken into account for identification of the coal streak age. The second radiocarbon dating after calibration refers the findings to the year 197-47 BC (Sigma 2) ${ }^{1}$. Therefore, the upper range of existence of the archaeological site with the Tyshkine (Senogda) pottery belongs to the $2^{\text {nd }}-$ first half of the $1^{\text {st }}$ millennium $\mathrm{BC}$.

The third radiocarbon dating was carried out with the coal streak found between the layers of the brown clay sand, where the Tyshkine (Senogda) pottery was found, and the yellow-grey clay sand, where the quartzite artefacts were found. This streak was detected only in the east from the central passageway. In other parts of plot 56, it is not present. From the coal streak, the date $3300 \pm 70$ (LE-11705) was acquired, which, with regard to calibration, re-

\footnotetext{
1 The dates and the error intervals were calibrated in Oxcal 4.2 software (Bronk Ramsey, 2009) using the IntCal13 database (Reimer et al., 2013).
} 
fers to the year 1740-1430 BC (95.4\%). According to this, the age of the early archaeological site of the second culture-bearing stratum may be determined as the early-middle $2^{\text {nd }}$ millennium BC.

\section{Conclusion}

Spiritual worldview played an important role in the life of the ancient people. That also included the ceremonies of collective address to the protector deities. Such ceremonies were usually held at the foot, on the slope or on the top of a hill, such as the cusp-like sites overlooking Lake Baikal. The geomorphological features of these natural altars have always attracted people, creating the impression of a place where the man may contact gods. One of such places is the rock ledge on Cape Ludar, which was significantly modified by people in the $1^{\text {st }}$ millennium AD. The ancient residents of the north-west coast of Lake Baikal completed the natural look of the ledge and the entire cusp-like plot with such protective structures as an earth mound and a dyke. They were built to separate the sacred territory from the mundane world, to protect it from any "harmful" influence.

The excavations carried out at the cusplike plot referred to as Baikalskoe-1 sanctuary fortress revealed two culture-bearing strata. The lower one belonged to the time when the special protective structures had not been erected. The findings lying in the second culture-bearing stratum date back to the $2^{\text {nd }}-1^{\text {st }}$ millennia BC. They consist of two archaeological sites, with the earlier one dating back to the early - mid $2^{\text {nd }}$ millennium BC. There, the remains of a ceramic Glazkov type pot and the quartzite items were found. At another archaeological site, the artefacts dating back to the $6^{\text {th }-} 1^{\text {st }}$ centuries $\mathrm{BC}$ were found, including the fragments of the Tyshkine (Senogda) type clay pots, arrowheads, scrapers and silicon knives, as well as wastes of their production.

Distinguishing two archaeological sites based on the items found in the second culture-bearing stratum of Baikalskoe-1 sanctuary fortress is mostly explained by their morphological nature and material they were made of. The earlier ones belong to the medium stage of the Bronze age, and the latter belong to the early Iron age. The presence of the Bronze age materials in Baikalskoe-1 proves the four thousand years' long existence of the stable religious worldview on the north-western coast of Lake Baikal, associated with the cusp-like sites and individual hills considered to be the transit zones, where people can contact deities. The proofs of this worldview can be found at the archaeological sites of the early Bronze age (Emel'ianova, Kharinskiy, 2008; Emel'ianova, 2010), though it might have started in the Neolith period. In different historical periods, different natural sites of the Baikal coast were believed to have different sacral qualities. At some of them, the ritual ceremonies would not be held any more forever; at others, the ceremonies would be suspended for a while to be resumed after some time. Baikalskoe-1 is one of such sanctuaries, which has gone through at least three periods of existence.

\section{References}

Abdulov, T.A., Bazaliyskiy, V.I. Berdnikova, N.E., Vetrov, V.M., Goriunova, O.I., Dziubas, S.A., Zadonin, O.V., Ingeshin, E.M., Titov, A.V., Fedorenko, A.B., Kharinskiy, A.V. (1988). Issledovaniia Irkutskogo universiteta [Research of the Irkutsk University]. In Arkheologicheskie otkrytiia 1986 g. [Archaeological discoveries of 1986], Moscow, 207-212.

Agapitov, N.N. (1881). Pribaykal'skie drevnosti [The Cisbaikal Antiquities], In: Izvestiia Vostochno-Sibirskogo otdeleniia russkogo geograficheskogo obshchestva [Bulletin of the East Siberian Branch of the Russian Geographical Society], 12 (4-5), 1-23.

Bazaliyskiy, V.I. (2010). Morfologicheskiy analiz kamennykh nakonechnikov strel mogil'nika "Lokomotiv" [Morphological Analysis of the Stone Arrowheads of the Lokomotiv Burial Ground]. In Izvestiia Laboratorii drevnikh tekhnologiy [Laboratory of Ancient Technologies' Newsletter], 8, 39-53.

Bronk Ramsey, C. (2009). Bayesian analysis of radiocarbon dates. In Radio-carbon, 51(1), 337-360. 
Emel'ianova, Iu.A. (2010). Naselenie severo-zapadnogo poberezh'ia Baykala v rannem bronzovom veke. Avtoreferat dissertatsii na soiskanie nauchnoy stepeni kandidata istoricheskikh nauk [Population of the North-Western Coast of Lake Baikal in the Early Bronze Age. Abstract of dissertation for the degree of Candidate of Historical Sciences], Barnaul, 23 p.

Emel'ianova, Iu.A., Kharinskiy, A.V. (2008). Drevneyshee gorodishche-sviatilishche na poberezh'e ozera Baykal [The Oldest Sanctuary Fortress by Lake Baikal]. In Izvestiia Laboratorii drevnikh tekhnologiy [Laboratory of Ancient Technologies' Newsletter], 6, 145-166.

Kichigin, D.E. (2010). Stoianka Krasnyy Iar II severo-zapadnogo poberezh'ia ozera Baykal: itogi i perspektivy [Krasny Iar II Camping Site on the North-Western Coast of Lake Baikal: Conclusions and Prospects]. In Izvestiia Laboratorii drevnikh tekhnologiy [Laboratory of Ancient Technologies' Newsletter], 8, 154-192.

Kharinskiy, A.V. (1994), "Gorodishcha" poberezh'ia ozera Baykal v zheleznom veke. Avtoreferat dissertatsii na soiskanie nauchnoy stepeni kandidata istoricheskikh nauk ["Fortifications" of the Coast of Lake Baikal in the Iron Age. Abstract of dissertation for the degree of Candidate of Historical Sciences], Novosibirsk, $18 \mathrm{p}$.

Kharinskiy, A.V. (2002a). Sviatilishcha v strukture prostranstvenno-territorial'nykh predstavleniy kudinskikh buriat [Sanctuaries in the Structure of the Spatial and Territorial Representations of the Kuda Buryats]. In: Narody i kul'tury Sibiri. Vzaimodeystvie kak faktor formirovaniia i modernizatsii [Peoples and Cultures of Siberia. Interaction as a Factor in the Formation and Modernization], Irkutsk, 121-135.

Kharinskiy, A.V. (2002b). Topografiia i konstruktsiia "gorodishch" malomorskogo poberezh'ia ozera Baykal [The Topography and Structure of the "Hillforts" of the Lesser Sea Coast of Lake Baikal]. In Arkheologicheskoe nasledie Baykal'skoy Sibiri: izuchenie, okhrana i ispol'zovanie [Archaeological Heritage of the Baikal Siberia: Studies, Protection and Use], Irkutsk, 2, 109-126.

Kharinskiy, A.V., Emel'ianova, Iu.A., Rykov, G.K. (2009). Severo-zapadnoe poberezh'e ozera Baykal v bronzovom veke: po materialam stoianok [The North-Western Coast of Lake Baikal in the Bronze Age: Based on the Camp Site Findings]. In Izvestiia Laboratorii drevnikh tekhnologiy [Izvestia Laboratory of Ancient Technologies], 7, 86-132.

Korotnev, A.A. (1901). Otchet po issledovaniiu ozera Baykal letom 1901 goda [Report on Exploration of Lake Baikal in the Summer of 1901]. In Iubileynyy sbornik: Fauna Baykala [Anniversary Collection: Fauna of Baikal], Kiev, 28-42.

Lotsiia i fiziko-geograficheskiy ocherk ozera Baykal [Navigational Instructions and the Physical-Geographical Sketch of Lake Baikal], St. Petersburg 1903, 443 p.

Reimer, P.J., Bard, E., Bayliss, A., Beck, J.W., Blackwell, P.G., Bronk Ramsey, C., Grootes, P.M., Guilderson, T.P., Haflidason, H., Hajdas, I., Hatte, C., Heaton, T.J., Hoffmann, D.L., Hogg, A.G., Hughen, K.A., Kaiser, K.F., Kromer B., Manning, S.W., Niu, M., Reimer, R.W., Richards, D.A., Scott, E.M., Southon, J.R., Staff, R.A., Turney, C.S.M., Van der Plicht, J. (2013). IntCal13 and Marine13 Radiocarbon Age Calibration Curves 0-50,000 Years cal BP. In Radiocarbon, 55 (4), 1869-1887.

Svinin, V.V. (1966). Arkheologicheskie issledovaniia na severnom poberezh'e ozera Baykal v 19631965 gg. [Archaeological Research on the Northern Coast of Lake Baikal in 1963-1965]. In Otchety arheologicheskikh ekspeditsiy za 1963-1965 gg. [Reports of Archaeological expeditions for 1963-1965], Irkutsk, $50-69$.

Tivanenko, A.V. (1990). Drevnee naskal'noe iskusstvo Buriatii [Ancient Cave Art of Buryatia], Novosibirsk, Nauka, 206 p. 


\title{
Начальный этап формирования городища-святилища Байкальское 1
}

\author{
A.В. Харинский \\ Иркутский национальный исследовательский технический университет \\ Российская Федераиия, Иркутск
}

\begin{abstract}
Аннотация. Городище-святилище Байкальское 1 расположено на северо-западном побережье озера Байкал. Оно занимает мысовидную скальную площадку мыса Лударь, возвышающуюся на 80 м над уровнем озера. В ходе раскопок на территории городища-святилища выделено два культуросодержащих слоя. Нижний включает артефакты II-I тыс. до н.э., которые разбиваются на два археологических комплекса. Более ранний из них предварительно датируется началом-серединой II тыс. до н.э. Он представлен остатками глиняного сосуда глазковского типа и изделиями из кварцита и кремня. Другой археологический комплекс включает артефакты, датирующиеся в пределах VI-I вв. до н.э. В их состав входят фрагменты глиняных сосудов тышкинейско-сеногдинского типа, наконечники стрел, скребки и ножи из кремня, а также отходы их производства. Находки, обнаруженные на Байкальском 1 , свидетельствуют о существовании на побережье Байкала на протяжении четырех тысячелетий устойчивых представлений о возвышенности как о месте, на котором возможны контакты между представителями мира людей и небожителями.
\end{abstract}

Ключевые слова: Байкал, мыс Лударь, городище-святилище, культуросодержащий слой, бронзовый век, керамика глазковского типа, изделия из кварцита, керамика тышкинейско-сеногдинского типа, наконечники стрел, скребки, радиоуглеродное датирование.

Публикация подготовлена в рамках поддержанного РГНФ научного проекта № 1531-01018.

Научная специальность: 07.00.00 - исторические науки и археология. 